\title{
Learn-to-swim program in a school context for a twelve-week period enhance aquatic skills and motor coordination in Brazilian children Las clases de natación en el contexto escolar durante un período de doce semanas mejoran las habilidades acuáticas y la coordinación motora en niños brasileños
}

\author{
*Orilda M. Moura, *Daniel A. Marinho, **Jorge E. Morais, *Mafalda P. Pinto, *Luís B. Faíl, *Henrique P. \\ Neiva \\ *University of Beira Interior (Portugal), **Instituto Politécnico de Bragança (Portugal)
}

\begin{abstract}
This study aimed to verify the effects of 12 weeks of swimming lessons implemented in age school Brazilian children's aquatic skills and motor coordination. Fifty children aged 6 to 10 years old (mean \pm SD: $8.34 \pm 1.10$ years), participated in one swimming lesson per week provided by the school curriculum. Each child was evaluated for their aquatic skills (17 skills checklist) and motor coordination (Körperkoordinationstest Für Kinder test-KTK) before and after the swimming program. This study showed significant improvements in the sum of scores obtained in swimming skills evaluation $(31.40 \pm 12.89$ vs. $46.90 \pm 10.73$ points, $p<.01, d=3.38)$. Large effects were found in water orientation and adjustment at the vertical position, breath control, horizontal buoyancy, body position at ventral, dorsal gliding and at longitudinal rotation, front and back somersaults, leg kicking with breath control, feet-first/head-first entries, autonomy in a deep pool and vertical buoyancy and immersion at deep water. The sum of scores in motor coordination assessment increased from $140.64 \pm 41.94$ to $175.20 \pm 41.39$ points $(p<.01, d=1.56)$. These results showed that 12 weeks of swimming practices, even conditioned by state school context (i.e., once a week), allowed Brazilian children aged 6-10 years old to increase aquatic skills and motor coordination.
\end{abstract}

Keywords: motor development, aquatic skills, swimming, child.

Resumen. Este estudio tuvo como objetivo verificar los efectos de las clases de natación durante un período de 12 semanas en las habilidades acuáticas y la coordinación motora en niños brasileños. Cincuenta niños entre los 6 y los 10 años de edad (media \pm DE: 8.34 \pm 1.10 años) participaron una vez por semana en una clase de natación ofrecida por el plan de estudios escolar. Cada niño fue evaluado en cuanto a sus habilidades acuáticas (lista de verificación de 17 habilidades) y coordinación motora (Körperkoordinationstest Für Kinder test - KTK) antes y después del programa de natación. Los resultados del estudio mostraron mejoras significativas en la suma de las puntuaciones obtenidas en la evaluación de las habilidades de natación $(31.40 \pm 12.89$ frente a $46.90 \pm 10.73$ puntos, $\mathrm{p}<.01, \mathrm{~d}=$ 3.38). Se observaran efectos importantes en la orientación y el ajuste del agua en la posición vertical, en el control de la respiración, en la flotabilidad horizontal, en la posición del cuerpo en la posición ventral, en el deslizamiento dorsal y la rotación longitudinal, en los saltos mortales hacia adelante y hacia atrás, en los empujes con las piernas con control de la respiración, pies primero / cabeza primero entradas, en la autonomía en piscina profunda y flotabilidad vertical y inmersión en aguas profundas. La suma de las puntuaciones en la evaluación de la coordinación motora aumentó de $140.64 \pm 41.94$ a $175.20 \pm 41.39$ puntos $(\mathrm{p}<.01, \mathrm{~d}=1.56)$. Estos resultados mostraron que 12 semanas de prácticas de natación, incluso condicionadas por el contexto de la escuela estatal (es decir, una vez por semana), permitieron a los niños brasileños de 6 a 10 años aumentar de forma significativa la preparación acuática y la coordinación motora. Palabras clave: desarrollo motor, habilidades acuáticas, natación, niño.

\section{Introduction}

Regular physical activity during childhood is recognised to provide beneficial effects in physiological and psychological variables, contribute to long-term healthy lifestyle habits and prevent diseases (Donnelly et al., 2016; Kuzik, Naylor, Spence, \& Carson, 2020). In this context, it seems imperative to ensure relevant,

Fecha recepción: 23-03-21. Fecha de aceptación: 09-07-21

Henrique P. Neiva

henriquepn@gmail.com diversified and age-appropriate motor experiences promoted in contexts of stimulating practices (Campaniço, Costa, Garrido, \& Silva, 2019). Several efforts have been made to increase the range of physical experiences, especially in schools, recognised as the primary institution responsible for promoting physical activity among young people (García-Hermoso et al., 2020). This way, several countries have made efforts to incorporate different sports practices in the school curriculum and swimming has emerged as part of it (Cardon, Verstraete, Clercq, \& Bourdeaudhuij, 2004; Stloukalová \& Roztoci, 2015). Besides being a different activity that would motivate the children to participate, 
swimming lessons could contribute to reducing the risk of drowning in children (Brenner, 2002; Brenner et al., 2009; Denny et al., 2019). Although people can learn to swim at any time, it is considered more convenient to begin swimming lessons at a younger age (Langerdorfer, 2019; Moura, Neiva, Faíl, Morais, \& Marinho, 2021). During this period, children can more easily learn and master the basic skills that are necessary not only to learn future swimming styles but also to be able to save their lives (Franklin et al., 2015; Rocha, Marinho, Ferreira, \& Costa, 2014). For these reasons, the inclusion of swimming lessons in the physical education curriculum is important and could contribute to active leisure and lifelong fitness (Cardon et al., 2004).

Previous research found that children improved performance in several aquatic skills, such as immersion and breath control, horizontal buoyancy, body position at ventral and dorsal gliding, and leg kicking with breath control at ventral body position, without any flutter device, after 6 months of swimming practices, twice a week (Rocha et al., 2018). A shorter period of swimming lessons (i.e., 8 weeks, twice a week) was also found to increase aquatic skills in 149 children aged 3-14 years old from a Latino-based community (Olaisen, Flocke, \& Love, 2018). It seems that the time needed to increase expertise in basic swimming skills could be related to the context and/or initial level of children (Campaniço et al., 2019; Clark, 2007). Furthermore, the swimming programs were suggested to cause more developments than just the simple acquisition of new motor patterns that allow moving inside the aquatic environment (Langendorfer \& Bruya, 1995; Martins et al., 2010). The learning or improvement of new motor skills, i.e., aquatic skills, provide new opportunities for learning and doing and consequently stimulate development changes in perceptual, cognitive and social domains of the children (Adolph, 2019; Adolph \& Franchak, 2017; Thelen, 1995). These development changes were recently verified in children between 5 and 10 years of age participating regularly in swimming lessons (Moura et al., 2021). The overall development of the child is sequential and cumulative, sustained in experiences that contribute to the enhancement of motor skills and the aquatic swimming skills could contribute to a large motor repertoire of movements and therefore contribute to future motor skillfulness (Gallahue \& Ozmun, 2005).

It is well known that the learning process and behavioural modifications imply repetition and systematisation (Campaniço et al., 2019). Most learn- to-swim programs assessed in previous studies comprised two or three sessions per week, for a long period (e.g., 6 months). However, in the real-life context, schools can only provide swimming lessons once a week and only for limited-time periods (e.g., three months). Although there is evidence that swimming instruction can build aquatic skills and also contribute to children's motor development (Bem, Cabelguen, Ekeberg, \& Grillner, 2003; Martins, Silva, Marinho, \& Costa, 2015; Moura et al., 2021), there is uncertainty about the effects of particular interventions contexts, such as those provided by schools in real situations. Therefore, there is a need for research that explores these factors (i.e., one session per week for short periods) in aquatic learning efficiency and motor development. The main purpose of the current study was to verify the effects of school-based swimming lessons for 12 weeks in aquatic skills and motor coordination in children aged 6-10 years old. It was hypothesised that aquatic specific skills and motor coordination test scores were significantly enhanced after this period.

\section{Material and Methods}

\section{Participants}

An experimental research design was used to verify the effects of swimming lessons for 12 weeks in aquatic skills and motor coordination in children aged 6-10 years old. The participants were recruited from a Brazilian state school in the city of Itumbiara-GO and were randomly selected among those who comprised the inclusion criteria, such as being healthy, attending school regular classes and swimming classes provided by the school curriculum. To participate in the current study, children had to be included in the regular school program. Children were excluded if they had any health problem, were not authorised by their guardians, or if they participated in a swimming training program and/ or other sport as a complement of the school lessons. Fifty children aged 6 to 10 years of age (mean \pm SD: $8.34 \pm 1.10$ years, $30.17 \pm 9.39 \mathrm{~kg}$ of body mass, 1.30 $\pm 0.10 \mathrm{~m}$ of height, and $17.42 \pm 3.68 \mathrm{~kg} / \mathrm{m}^{2}$ of body mass index) were included in the current study. Among these, $48 \%$ were boys and $52 \%$ were girls, and 13 attended the first grade $(6.85 \pm .38$ years, $24.45 \pm$ $\left.5.18 \mathrm{~kg}, 1.21 \pm .06 \mathrm{~m}, 16.56 \pm 2.96 \mathrm{~kg} / \mathrm{m}^{2}\right), 10$ the second grade $(8.00 \pm .00$ years, $28.37 \pm 6.74 \mathrm{~kg}, 1.26$ $\left.\pm .06 \mathrm{~m}, 17.66 \pm 2.50 \mathrm{~kg} / \mathrm{m}^{2}\right), 12$ the third grade $(8.92 \pm .51$ years, $33.82 \pm 10.97 \mathrm{~kg}, 1.35 \pm .05 \mathrm{~m}$, 
$\left.18.28 \pm 4.59 \mathrm{~kg} / \mathrm{m}^{2}\right)$, and 15 the fourth grade $(9.40 \pm$ .51 years, $33.42 \pm 10.30 \mathrm{~kg}, 1.38 \pm .09 \mathrm{~m}, 17.30 \pm$ $4.24 \mathrm{~kg} / \mathrm{m}^{2}$ ). All children and parents/guardians were informed about the experimental procedures of the study, and after acceptance, the parents / guardians signed the informed consent. Data confidentiality was guaranteed, as well as their anonymity during the treatment process and analysis. The local swimming school board and the University of Beira Interior Review Board approved the study procedures, in accordance with the Declaration of Helsinki.

\section{Aquatic skills assessment}

The participants were evaluated twice for their aquatic skills, before and after the swimming program that lasted for 12 weeks. For this evaluation, it was used an observation checklist of 17 aquatic specific skills, validated by Langerdorfer and Bruya (1995) and applied in recent studies on swimming proficiency (e.g., Costa et al., 2012; Rocha et al., 2018). Each child performed one familiarisation session before the evaluation. The assessed aquatic motor skills were: water entry (Sk1); water orientation and adjustment at vertical position (Sk2); breath control - immersion of the face and eyeopening (Sk3); horizontal buoyancy (Sk4); body position at ventral gliding (Sk5); body position at dorsal gliding (Sk6); body position at longitudinal rotation in gliding (Sk7); body position at front and back somersaults (Sk8); leg kicking with breath control at ventral body position, with flutter boards (Sk9); and without any flutter device (Sk10); leg kicking with breath control at dorsal body position with flutter boards (Sk11); and without any flutter device (Sk12); feet-first entry (Sk13); head-first entry (Sk14); autonomy in a deep pool (legs and arms displacement) (Sk15); vertical buoyancy at deep water (Sk16); deep water immersion (Sk17). These skills comprised different levels of complexity, from 3 to 5 , as suggested by Lagenderfer and Bruya (1995) and defined the level of mastery in each specific skill. The assessment of these skills was performed by the main researcher. Each exercise was explained and exemplified, ensuring that all the participants understood the skill that was asked to perform. Each participant had three attempts to perform the proposed exercises and when unable to perform any of the tries, it was settled as level 1. The scores ranged from level 1 (minimum) to 3 (maximum) for Sk1, Sk2, Sk7, Sk13, Sk14, and Sk15; from level 1 to 4 for Sk4, Sk5, Sk6, Sk8, Sk9, Sk10, Sk11, Sk12, and Sk17; and from level 1 to 5 for Sk3 and Sk16. The sum of results in each swimming skill evaluation was calculated for further analysis. Two cameras were used (Canon EOS Rebel T6i + EF-S 1855mm f / 3.5-5.6 IS STM, Tokyo, Japan), one positioned frontally and the other laterally to the skill performed by the child. This was then used to confirm previous manual evaluations performed in the swimming pool.

\section{Motor coordination}

The motor coordination of the participants was assessed through the application of Körperkoordinationstest Für Kinder test (KTK), developed by Kiphard and Schilling (1974) and applied to children since then (e.g. Lopes, Rodrigues, Maia, \& Malina, 2011; Moreira et al., 2019). This is a is a reliable and low-cost motor coordination test validated for Brazilian children aged 5 - 10 years old (Moreira et al., 2019). Each participant was evaluated in four tasks: i) walking backwards along a balance beam with decreasing width, $6 \mathrm{~cm}, 4.5 \mathrm{~cm}$, and $3 \mathrm{~cm}(\mathrm{WB})$; ii) two-legged jumping from side to side for $15 \mathrm{~s}$ (JS); iii) moving sideways on wooden boards for $20 \mathrm{~s}$ (MS); and iv) one-legged hopping for height $(\mathrm{HH})$ over a foam obstacle with in-creasing height in consecutive steps of $5 \mathrm{~cm}$ (Rudd et al., 2015). These four subtests were evaluated in this order: WB, JS, MS and $\mathrm{HH}$, following the guidelines by the authors (Kiphard \& Schilling, 1974). It is known that these tasks involve components of motor coordination such as balance, rhythm, strength, laterality, speed and agility (Scordella et al., 2015). The sum of raw scores of the subtests was calculated for further analysis. The evaluation was performed individually by the main researcher and then confirmed by video analysis. All the assessments were recorded by two cameras (Canon EOS Rebel T6i + EF-S 18-55mm f / 3.5-5.6 IS STM, Tokyo, Japan), one positioned frontally and one laterally to the performed task. The KTK assessment was performed before and after the swimming program and each child was familiarised with the tasks to perform in the week before the first assessment.

\section{Swimming practice}

The swimming lessons were implemented for 12 weeks (September to December), once a week, in sessions that lasted for $50 \mathrm{~min}$. These sessions were carried out in a $20 \mathrm{~m}$ swimming pool, $1 \mathrm{~m}$ water depth, with a water temperature of $28^{\circ} \mathrm{C}$. The lessons were divided according to the students' grades (first, second, third and fourth grade) and the number of students ranged from 5 to 12 in each lesson. The swimming lessons were carried out by two swimming teachers, and the 
teaching methods, as well as the skills developed in each class, were similar and according to the literature guidelines (e.g. Barbosa et al., 2013; Campaniço et al., 2019). A researcher was present throughout the intervention period to monitor the swimming lessons. The number of students was kept minimal to increase the useful time of the lesson and minimize practice waiting time among students. This allowed to use the small group teaching method most of the time, but under certain circumstances, individualized instruction was also used (for example, to make specific corrections or to help the student with some exercise issues).

The swimming lessons were based on a progressive behavioral change of children, resulting from the sequential learning of basic movement skills. The first sessions were used to promote the student's familiarisation with the aquatic environment, promote the creation of autonomy in the aquatic environment and create the basis for later acquisition of specific aquatic motor skills. The main contents were related to the aquatic environment adaptation and the development of basic aquatic skills (i.e. familiarisation, balance, breathing, jumping, and elementary propulsion). Moreover, the practice of higher complexity motor skills was only performed after lower complexity motor skills consolidation. In the first part of the lesson, some preparatory/warm-up exercises were performed, including tasks remembering previously acquired skills. In the main part of the lesson, exercises focused on the development and/or consolidation of specific skills according to the objective. In this part, the students mainly performed analytical tasks. In the final part of the lesson, some games/ludic tasks were included, leading the child to exercise/discover a predetermined aquatic skill in response to some problems presented by the teacher. The teaching styles used during the swimming lessons were oriented towards a direct instruction style (mainly in the main part of the lesson) in combination with a guided discovery style (mainly in the final part of the lesson). The students were stimulated to learn by practising as much movement as possible through repetition of some tasks but also using variations in the exercise forms.

\section{Statistical analysis}

A priori sample size was calculated for an á error probability of 0.05 and a power ( 1 - â) of 0.80 , suggesting that a minimum of 24 participants should be included to detect a moderate effect size $(>0.6)$ (GPower, v.3.1.7, University of Kiel, Germany). Standard statistical methods were used for the calculation of means, standard deviations (SDs) and median values. The Normality of data distribution was assessed by the Kolmogorov-Smirnov test. The swimming skills data were non-parametric and consequently, the Wilcoxon signed ranks tests were used to compare initial values vs. final values in each skill. Motor coordination subtests results were normally distributed and the pairedsamples t-test was used to assess the differences between evaluation moments. The effect size was computed to analyse the differences between pre and postintervention for each variable. An effect size calculator for non-parametric tests (i.e. swimming skills) was used to determine eta square and then transforming into Cohen $d$ values for standardization (Dunlap, 1994; Borenstein, Hedges, Higgins, \& Rothstein, 2009; Lenhard \& Lenhard, 2016). For normally distributed variables (i.e., KTK results), Cohen $d$ was determined. A $d$ value $<.2$ was considered a trivial effect, .2 to .6 a small effect, .6 to 1.2 a moderate effect, 1.2 to 2.0 a large effect, 2.0 to 4.0 a very large effect, and e» 4.0 an extremely large effect (Hopkins, Marshall, Batterham, \& Hanin, 2009). The criterion for significance was set at an alpha level of $p<.05$. The software IBM SPSS Statistics for Windows (version 27.0., IBM Corp., Armonk, NY, USA) was used for all statistical analyses.

\section{Results}

The results of the skills evaluated before and after the swimming lessons for all participants are presented in Table 1. The swimming lessons showed a very large effect in the sum of scores obtained in the swimming skills assessment (31.40 \pm 12.89 points vs. $46.90 \pm 10.73$ points, $p<.01, d=3.38)$. Moreover, improvements were also found in motor coordination. The sum of scores in motor coordination assessment increased from 140.64

\begin{tabular}{|c|c|c|c|c|c|c|c|c|c|}
\hline \multirow[t]{2}{*}{ Skills } & \multirow{2}{*}{$\begin{array}{c}\text { Levels of } \\
\text { complexity }\end{array}$} & \multicolumn{3}{|c|}{ Pre } & \multicolumn{3}{|c|}{ Post } & \multicolumn{2}{|c|}{ Pre vs. Post } \\
\hline & & Mean & SD & Median & Mean & SD & Median & $p$-value & $d$ \\
\hline Skill 1 & $1-3$ & 2.98 & .14 & 3 & 3.00 & .00 & 3 & .32 & .29 \\
\hline Skill 2 & $1-3$ & 2.34 & .48 & 2 & 2.64 & .49 & 3 & $<.01 * *$ & 1.37 \\
\hline Skill 3 & $1-5$ & 3.50 & 1.22 & 3 & 4.20 & .95 & 5 & $<.01 * *$ & 1.15 \\
\hline Skill 4 & $1-4$ & 1.56 & 1.57 & 2 & 2.92 & .99 & 3 & $<.01 * *$ & 1.70 \\
\hline Skill 5 & $1-4$ & 1.96 & 1.60 & 2 & 3.28 & 1.07 & 4 & $<.01 * *$ & 1.77 \\
\hline Skill 6 & $1-4$ & 0.98 & 1.36 & 0 & 2.46 & 1.09 & 2 & $<.01 * *$ & 1.92 \\
\hline Skill 7 & $1-3$ & 1.46 & 1.16 & 2 & 2.32 & .65 & 2 & $<.01 * *$ & 1.73 \\
\hline Skill 8 & $1-4$ & .60 & 1.07 & 0 & 2.02 & .85 & 2 & $<.01 * *$ & 1.96 \\
\hline Skill 9 & $1-4$ & 2.02 & 1.06 & 2 & 3.00 & 1.05 & 3 & $<.01 * *$ & 1.81 \\
\hline Skill 10 & $1-4$ & 1.84 & 1.24 & 2 & 2.82 & .96 & 2 & $<.01 * *$ & 1.77 \\
\hline Skill 11 & $1-4$ & 1.46 & 1.23 & 2 & 2.80 & .99 & 2 & $<.01 * *$ & 2.04 \\
\hline Skill 12 & $1-4$ & 1.20 & 1.21 & 2 & 2.48 & .93 & 2 & $<.01 * *$ & 2.00 \\
\hline Skill 13 & $1-3$ & 1.94 & 0.74 & 2 & 2.50 & .51 & 2.5 & $<.01 * *$ & 1.44 \\
\hline Skill 14 & $1-3$ & 1.34 & .98 & 2 & 2.36 & .60 & 2 & $<.01 * *$ & 2.04 \\
\hline Skill 15 & $1-3$ & 1.28 & 1.11 & 2 & 2.02 & .69 & 2 & $<.01 * *$ & 1.44 \\
\hline Skill 16 & $1-5$ & 3.42 & 1.95 & 4 & 4.56 & .79 & 5 & $<.01 * *$ & 1.31 \\
\hline Skill 17 & $1-4$ & 1.52 & 1.79 & 0 & 2.92 & 1.32 & 4 & $<.01 * *$ & 1.19 \\
\hline
\end{tabular}


\pm 41.94 to $175.20 \pm 41.39$ points $(p<.01, d=1.56)$. An overview of the raw scores of the subtests is presented in Figure 1. Among these, the hopping for height was the subtest with the lowest effect size.

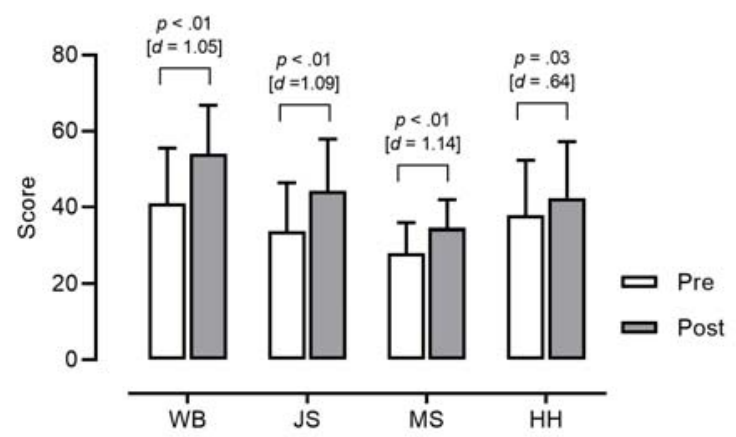

Figure 1.

Mean values (and standard deviation) of subtests walking backwards (WB), jumping sideways (JS), moving sideways (MS), hoping for height (HH) before (Pre) and after (Post) intervention in all participants $(n=$ 50). P-values and effect sizes (Cohen's d) are also presented.

The sum of scores in aquatic skills assessment increased from $23.00 \pm 10.00$ to $40.62 \pm 5.28$ points $(p$ $<.01, d=3.75), 24.50 \pm 12.36$ to $42.40 \pm 14.56$ points $(p<.01, d=3.87), 36.83 \pm 10.43$ to $51.33 \pm$ 8.16 points $(p<.01 . d=3.77), 38.93 \pm 11.25$ to 51.80 \pm 9.83 points $(p<.01, d=3.26)$ in the first, second, third and fourth grade, respectively. Table 2, Table 3, Table 4 and Table 5 present the swimming skills

Table 2 .

Mean standard deviation (SD) and median values of first grade (6-7 years old, $n=13)$ before (pre) and after swimming lessons (post). P-value and effect size (d) are also presented.

\begin{tabular}{|c|c|c|c|c|c|c|c|c|c|}
\hline \multirow[t]{2}{*}{ Skills } & \multirow{2}{*}{$\begin{array}{c}\text { Levels of } \\
\text { complexity }\end{array}$} & \multicolumn{3}{|c|}{ Pre } & \multicolumn{3}{|c|}{ Post } & \multicolumn{2}{|c|}{ Pre vs. Post } \\
\hline & & Mean & SD & Median & Mean & SD & Median & $p$-value & $d$ \\
\hline Skill 1 & $1-3$ & 3.00 & .00 & 3 & 3.00 & .00 & 3 & 1.00 & 0 \\
\hline Skill 2 & $1-3$ & 2.15 & .38 & 2 & 2.23 & .44 & 2 & .32 & .58 \\
\hline Skill 3 & $1-5$ & 3.38 & 1.33 & 3 & 4.08 & 1.04 & 5 & .07 & 1.15 \\
\hline Skill 4 & $1-4$ & 1.31 & 6.30 & 1 & 2.62 & .77 & 2 & $<.01 * *$ & 3.05 \\
\hline Skill 5 & $1-4$ & 1.54 & .88 & 1 & 2.85 & .99 & 2 & $<.01 * *$ & 3.05 \\
\hline Skill 6 & $1-4$ & 1.08 & .28 & 1 & 1.62 & .51 & 2 & $<.01 * *$ & 2.17 \\
\hline Skill 7 & $1-3$ & 1.46 & .52 & 1 & 2.00 & .41 & 2 & $.02 *$ & 1.70 \\
\hline Skill 8 & $1-4$ & 1.38 & .77 & 1 & 2.23 & .83 & 2 & $<.01 * *$ & 2.12 \\
\hline Skill 9 & $1-4$ & 1.69 & .48 & 2 & 2.08 & .49 & 2 & $.03 *$ & 1.60 \\
\hline Skill 10 & $1-4$ & 1.69 & .63 & 2 & 2.31 & .63 & 2 & $<.01 * *$ & 2.55 \\
\hline Skill 11 & $1-4$ & 1.54 & .66 & 1 & 2.08 & .28 & 2 & $<.01 * *$ & 2.17 \\
\hline Skill 12 & $1-4$ & 1.38 & .51 & 1 & 2.15 & .38 & 2 & $<.01 * *$ & 2.67 \\
\hline Skill 13 & $1-3$ & 1.92 & .49 & 2 & 2.31 & .48 & 2 & .10 & 1.03 \\
\hline Skill 14 & $1-3$ & 1.54 & .52 & 2 & 2.31 & .63 & 2 & $<.01 * *$ & 2.17 \\
\hline Skill 15 & $1-3$ & 1.38 & .51 & 1 & 1.77 & .60 & 2 & $.03 *$ & 1.60 \\
\hline Skill 16 & $1-5$ & 3.08 & 1.75 & 4 & 4.23 & 1.09 & 4 & $.04 *$ & 1.37 \\
\hline Skill 17 & $1-4$ & 1.23 & .44 & 1 & 2.23 & 1.30 & 2 & $.02 *$ & 1.77 \\
\hline
\end{tabular}

Table 3.

Mean standard deviation (SD) and median values of second grade (7-8 years old, $n=10)$ before (pre) and after swimming lessons (post). P-value and effect size (d) are also presented.

\begin{tabular}{|c|c|c|c|c|c|c|c|c|c|}
\hline \multirow[t]{2}{*}{ Skills } & \multirow{2}{*}{$\begin{array}{c}\text { Levels of } \\
\text { complexity }\end{array}$} & \multicolumn{3}{|c|}{ Pre } & \multicolumn{3}{|c|}{ Post } & \multicolumn{2}{|c|}{ Pre vs. Post } \\
\hline & & Mean & SD & Median & Mean & SD & Median & $p$-value & $d$ \\
\hline Skill 1 & $1-3$ & 3.00 & .00 & 3 & 3.00 & .00 & 3 & 1.00 & 0 \\
\hline Skill 2 & $1-3$ & 2.40 & .52 & 2 & 2.90 & .32 & 3 & $.03 *$ & 2.00 \\
\hline Skill 3 & $1-5$ & 3.20 & 1.32 & 3 & 4.20 & 1.14 & 5 & $.04 *$ & 1.70 \\
\hline Skill 4 & $1-4$ & 1.70 & .95 & 1.5 & 2.50 & 1.27 & 2.5 & $.04 *$ & 1.74 \\
\hline Skill 5 & $1-4$ & 1.70 & .95 & 1.5 & 2.70 & 1.42 & 3 & .06 & 1.47 \\
\hline Skill 6 & $1-4$ & 1.50 & 1.08 & 1 & 2.40 & 1.08 & 2 & $.02 *$ & 2.04 \\
\hline Skill 7 & $1-3$ & 1.30 & .48 & 1 & 2.00 & .67 & 2 & $.02 *$ & 2.17 \\
\hline Skill 8 & $1-4$ & 1.10 & .32 & 1 & 1.60 & .52 & 2 & $.03 *$ & 2.00 \\
\hline Skill 9 & $1-4$ & 2.30 & 1.06 & 2 & 3.00 & .94 & 3 & $.02 *$ & 2.17 \\
\hline Skill 10 & $1-4$ & 1.90 & .99 & 2 & 2.70 & 1.16 & 2 & $.02 *$ & 2.08 \\
\hline Skill 11 & $1-4$ & 1.60 & .91 & 1 & 2.50 & 1.18 & 2 & $.04 *$ & 1.74 \\
\hline Skill 12 & $1-4$ & 1.50 & .97 & 1 & 2.30 & 1.16 & 2 & $.04 *$ & 1.70 \\
\hline Skill 13 & $1-3$ & 1.80 & .42 & 2 & 2.60 & .52 & 3 & $.02 *$ & 2.08 \\
\hline Skill 14 & $1-3$ & 1.40 & 0.52 & 1 & 2.40 & .70 & 2.5 & $<.01 * *$ & 3.05 \\
\hline Skill 15 & $1-3$ & 1.20 & .42 & 1 & 1.60 & .52 & 2 & $.05 *$ & 1.63 \\
\hline Skill 16 & $1-5$ & 3.50 & 1.78 & 4 & 4.70 & .48 & 5 & .07 & 1.43 \\
\hline Skill 17 & $1-4$ & 1.40 & .97 & 1 & 2.30 & 1.25 & 2 & $.04 *$ & 1.74 \\
\hline
\end{tabular}

evaluated before and after the intervention period in each school grade. Large to very large effects caused by the swimming lessons were found in most skills, specifically from skill 3 to skill 17 in the first grade and from skill 2 to skill 17 in the second, third and fourth grades.

\begin{tabular}{|c|c|c|c|c|c|c|c|c|c|}
\hline \multirow[t]{2}{*}{ Skills } & \multirow{2}{*}{$\begin{array}{c}\text { Levels of } \\
\text { complexity }\end{array}$} & \multicolumn{3}{|c|}{ Pre } & \multicolumn{3}{|c|}{ Post } & \multicolumn{2}{|c|}{ Pre vs. Post } \\
\hline & & Mean & SD & Median & Mean & $\mathrm{SD}$ & Median & $p$-value & $d$ \\
\hline $\begin{array}{l}\text { Skill } 1 \\
\end{array}$ & $1-3$ & 2.92 & .29 & 3 & 3.00 & .00 & 3 & .32 & .59 \\
\hline Skill 2 & $1-3$ & 2.33 & .49 & 2 & 2.75 & .45 & 3 & $.03 *$ & 1.70 \\
\hline Skill 3 & $1-5$ & 3.83 & 1.03 & 4 & 4.25 & .75 & 4 & .06 & 1.31 \\
\hline Skill 4 & $1-4$ & 2.58 & 1.17 & 3 & 3.42 & .79 & 4 & $.02 *$ & 1.81 \\
\hline Skill 5 & $1-4$ & 2.75 & .97 & 3 & 3.50 & 1.00 & 4 & $.04 *$ & 1.50 \\
\hline Skill 6 & $1-4$ & 1.67 & .49 & 2 & 2.67 & .89 & 2 & $.01 * *$ & 2.26 \\
\hline Skill 7 & $1-3$ & 2.08 & .52 & 2 & 2.67 & .49 & 3 & $<.01 * *$ & 2.35 \\
\hline Skill 8 & $1-4$ & 1.50 & .80 & 1 & 2.25 & 1.14 & 2 & $<.01 * *$ & 2.50 \\
\hline Skill 9 & $1-4$ & 2.33 & .89 & 2 & 3.50 & .91 & 4 & $<.01 * *$ & 2.35 \\
\hline Skill 10 & $1-4$ & 2.00 & .74 & 2 & 3.00 & 1.04 & 3 & $.01 * *$ & 2.04 \\
\hline Skill 11 & $1-4$ & 2.00 & .74 & 2 & 3.25 & .97 & 4 & $<.01 * *$ & 2.67 \\
\hline Skill 12 & $1-4$ & 1.92 & .79 & 2 & 2.75 & .97 & 2 & $.02 *$ & 1.96 \\
\hline Skill 13 & $1-3$ & 2.00 & .43 & 2 & 2.42 & .52 & 2 & $.03 *$ & 1.70 \\
\hline Skill 14 & $1-3$ & 1.75 & .05 & 2 & 2.17 & .58 & 2 & $.03 *$ & 1.70 \\
\hline Skill 15 & $1-3$ & 1.92 & .52 & 2 & 2.25 & .62 & 2 & $.05 *$ & 1.40 \\
\hline Skill 16 & $1-5$ & 3.92 & 1.24 & 4 & 4.75 & .45 & 5 & $.04 *$ & 1.47 \\
\hline Skill 17 & $1-4$ & 2.42 & 1.44 & 2 & 3.50 & 1.17 & 4 & $.04 *$ & 1.50 \\
\hline
\end{tabular}

** $p \leq 0.01 ; * \mathrm{p} \leq 0.05$

Table 5 .

Mean standard deviation (SD) and median values of fourth grade (9-10 years old, $n=15$ ) before (pre) and after swimming lessons (post). P-value and effect size (d) are also presented.

\begin{tabular}{|c|c|c|c|c|c|c|c|c|c|}
\hline \multirow[t]{2}{*}{ Skills } & \multirow{2}{*}{$\begin{array}{l}\text { Levels of } \\
\text { complexity }\end{array}$} & \multicolumn{3}{|c|}{ Pre } & \multicolumn{3}{|c|}{ Post } & \multicolumn{2}{|c|}{ Pre vs. Post } \\
\hline & & Mean & SD & Median & Mean & SD & Median & $p$-value & $d$ \\
\hline Skill 1 & $1-3$ & 3.00 & .00 & 3 & 3.00 & .00 & 3 & 1.00 & 0 \\
\hline Skill 2 & $1-3$ & 2.40 & .51 & 2 & 2.73 & .46 & 3 & $.03 *$ & 1.40 \\
\hline Skill 3 & $1-5$ & 3.53 & .99 & 3 & 4.27 & .96 & 5 & .09 & .97 \\
\hline Skill 4 & $1-4$ & 2.40 & 1.18 & 3 & 3.07 & .96 & 3 & .06 & 1.12 \\
\hline Skill 5 & $1-4$ & 3.00 & 1.25 & 4 & 3.87 & .52 & 4 & $.02 *$ & 1.57 \\
\hline Skill 6 & $1-4$ & 2.07 & 1.22 & 2 & 3.07 & 1.22 & 4 & $.01 * *$ & 1.77 \\
\hline Skill 7 & $1-3$ & 2.27 & .80 & 2 & 2.53 & .74 & 3 & $.05 *$ & 1.22 \\
\hline Skill 8 & $1-4$ & 1.33 & .62 & 1 & 1.93 & .70 & 2 & $.01 * *$ & 1.63 \\
\hline Skill 9 & $1-4$ & 2.33 & .72 & 2 & 3.40 & 1.12 & 4 & $<.01 * *$ & 2.12 \\
\hline Skill 10 & $1-4$ & 2.60 & .99 & 2 & 3.20 & .86 & 3 & $.02 *$ & 1.44 \\
\hline Skill 11 & $1-4$ & 2.07 & .88 & 2 & 3.27 & .88 & 4 & $<.01 * *$ & 2.50 \\
\hline Skill 12 & $1-4$ & 1.80 & .78 & 2 & 2.67 & 1.05 & 2 & $<.01 * *$ & 2.00 \\
\hline Skill 13 & $1-3$ & 2.33 & .49 & 2 & 2.67 & .49 & 3 & $.03 *$ & 1.40 \\
\hline Skill 14 & $1-3$ & 1.93 & .46 & 2 & 2.53 & .52 & 3 & $<.01 * *$ & 1.96 \\
\hline Skill 15 & $1-3$ & 2.07 & .70 & 2 & 2.33 & .72 & 2 & $.05 *$ & 1.22 \\
\hline Skill 16 & $1-5$ & 4.00 & 1.46 & 5 & 4.60 & .83 & 5 & $.05 *$ & 1.19 \\
\hline Skill 17 & $1-4$ & 2.93 & 1.39 & 4 & 3.47 & 1.13 & 4 & .26 & .63 \\
\hline
\end{tabular}

Just as the results of the entire sample, the motor coordination in each grade was found to be greatly improved from pre to post evaluation. The values of motor coordination changed from a total raw score of $110.23 \pm 20.52$ to $147.23 \pm 30.10$ points $(p<.01, d=$ $1.69)$ in the first grade, $137.90 \pm 38.44$ to $176.70 \pm$ 35.71 points $(p<.01, d=2.30)$ in the second grade, $143.33 \pm 37.39$ to $175.92 \pm 35.44$ points $(p<.01, d=$

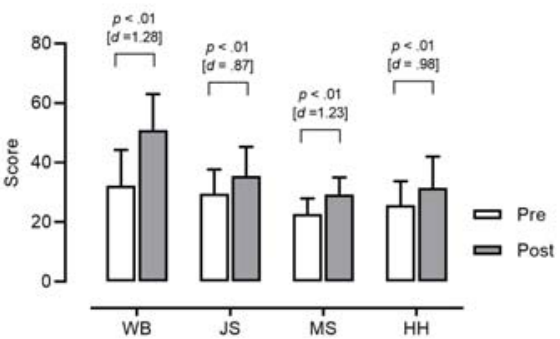

Figure 2

Mean values (and standard deviation) of subtests walking backwards (WB), jumping sideways (JS), moving sideways (MS), hoping for height (HH) before (Pre) and after (Post) intervention in the first grade. $P_{\text {-values }}$ and effect sizes (Cohen's $d$ ) are also presented. 
$1.41)$ in the third grade, and $164.27 \pm 47.51$ to 197.87 \pm 46.20 points $(p<.01, d=1.23)$ in the fourth grade. An overview of the subtests raw scores separated by grade is presented in Figure 2-5.

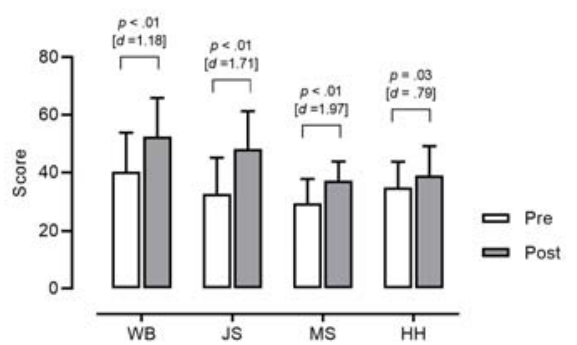

Figure 3.

Mean values (and standard deviation) of subtests walking backwards (WB), jumping sideways (JS), moving sideways (MS), hoping for height (HH) before (Pre) and after (Post) intervention in the second grade. P. values and effect sizes (Cohen's d) are also presented.

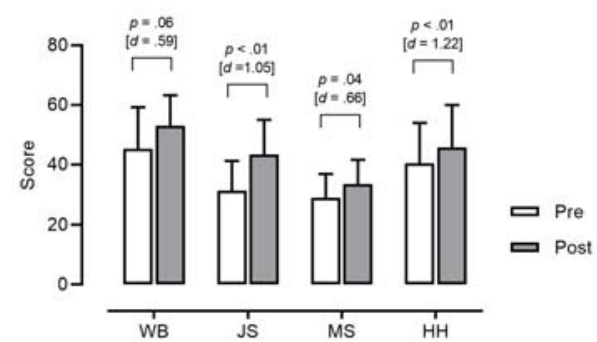

Figure 4 .

Mean values (and standard deviation) of subtests walking backwards (WB), jumping sideways (JS), moving sideways (MS), hoping for height (HH) before (Pre) and after (Post) intervention the third grade. P-values and effect sizes (Cohen's d) are also presented.

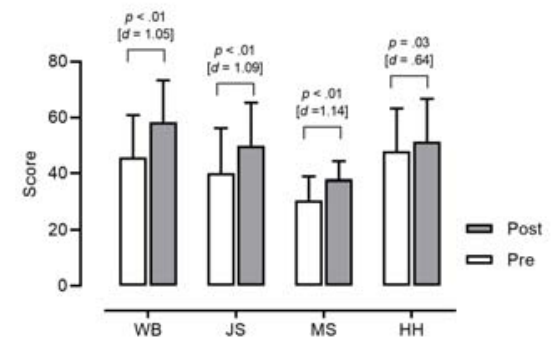

Figure 5 .

Mean values (and standard deviation) of subtests walking backwards (WB), jumping sideways (JS), moving sideways (MS), hoping for height (HH) before (Pre) and after (Post) intervention in the fourth grade. $P$ values and effect sizes (Cohen's $d$ ) are also presented.

\section{Discussion}

The primary aim of the current study was to verify the effects of swimming lessons implemented in a school context for 12 weeks in aquatic skills and motor coordination in 6-10 years old children. The results of this study showed that three months of swimming practices once a week were sufficient to allow children to develop aquatic specific skills in most of the aquatic basic skills, except in the water entry skill, which was already at a high level. These improvements were accompanied by increased motor coordination in the KTK test outcomes. This highlights the fact that learnto-swim practice at school contributes to the aquatic skills development and increased motor coordination of Brazilian children.

Previous research on young children found that six months of swimming practices in shallow or deep-water conditions allowed students to develop aquatic specific skills (Rocha et al. , 2018). Interestingly, a shorter duration (i.e., 8 weeks) was also found to be effective at building aquatic skills in children aged 3-14 from a Latino-based community (Olaisen, Flocke, \& Love, 2018). These effects were found after training programs that comprised swimming practices at least twice a week. However, the reality of most Brazilian public schools only allows children to practice this sport once a week. Until now, there was no evidence suggesting that a swimming program with high constraints regarding training frequency provided any benefit for children. In the current study, swimming skills were improved from pre to post-intervention, with large effects in almost all evaluated swimming skills. No improvement in the water entry skill was registered mainly because the initial evaluation was already close to maximum. The greater effects were found in horizontal buoyancy, body position at ventral gliding, body position at dorsal gliding, body position at longitudinal rotation in gliding, body position at front and back somersaults, leg kicking with breath control at ventral body position and leg kicking with breath control at dorsal body position. On the other side, the smaller effects were found in breath control, specifically the immersion of the face and eye-opening and the deep-water immersion. In most of these skills, children did not attain mastery after the intervention, which suggests a need for more stimulation for the complete acquisition of basic skills (Gallahue \& Ozmun, 2005).

In the current study, the younger children (6-7 years old) showed greater enhancements in horizontal buoyancy (Sk4) and body position at ventral gliding (Sk5). For the participants attending the second grade, higher improvements were found in the head-first entry (Sk14). For the third and fourth grades, the major enhancements were found in leg kicking with breath control at dorsal body position with flutter boards. Most of the swimming skills were improved from the pre to the post-intervention period, mostly because of the low values in the initial evaluation. In a general analysis, the younger children have shown to develop skills usually associated with buoyancy and gliding. In the older ones, the greater development was found in skills more related to horizontal body position, and leg kicking. Some caution should be made regarding aquatic basic skills, such as 
water orientation and adjustment at the vertical position and breath control, as they were expected to be more developed (Costa et al., 2012; Rocha et al., 2018). The twelve lessons of the current swimming program were not enough to attain mastery in these basic skills, and this can comprise a future swimming learning process. Moreover, a higher frequency of swimming lessons could be important to attain mastery of swimming skills that could be essential, for instance, to drowning prevention (Chan, Lee, Macfarlane, Hagger \& Hamilton, 2020). The learn-to-swim programs should be carefully planned to experience certain basic skills so that children can attain mastery domain of these skills. This would allow the acquisition of more advanced skills and provide increased water safety (Langendorfer \& Bruya, 1995). Initially, the children should get familiarised with the water, and then, basic aquatic skills can be learned, such as floating, buoyancy, gliding, diving and breathing skills (Langendorfer \& Bruya, 1995, Barbosa et al., 2013). Only then, with the basic aquatic skills properly developed, should the swimming strokes be taught (Langendorfer \& Bruya, 1995).

Most learn-to-swim programs are based on the need to adjust a child's motor behaviour in the water, understanding the concepts associated with the new environment, such as a lower gravity and viscosity, balance, thrust, and propulsion (Barbosa et al., 2013; Langendorfer \& Bruya, 1995). This implies more than just the acquisition of specific skills and it could influence motor skills development (Martins et al., 2015; Moura et al., 2021). In the current study, the motor coordination of children aged 6-10 years old changed positively from pre to post-intervention with great effects on the sum of the KTK assessment scores. The improvement in walking backwards, jumping sideways, moving sideways, and hopping for height scores clearly demonstrated the progress in tasks involving motor coordination components such as balance, rhythm, strength, laterality, speed and agility (Scordella et al., 2015).

The improvements in KTK scores found in each school year, from the first to the fourth grade could be the consequence of an increase in physical activity. In the present study, the swimming lessons started at the beginning of the school year, and before that no systematic and regular activity was provided to the children. Previous studies have found that motor coordination measured by the four items of the KTK test is a significant predictor of physical activity in children aged 6 to 10 years (Lopes et al., 2011). This age period seems to be conducive to improvement in general motor coordination, allowing the achievement of increasingly complex movements (Gallahue \& Ozmun, 2005). This improvement in motor coordination could be influenced by the different motor skills that children are exposed to (Adolph, 2019; Adolph \& Franchak, 2017; Thelen, 1995). Therefore, it is important to provide enough physical activity and several motor skills stimulations since childhood (Lopes, Rodrigues, Maia, \& Malina, 2011; Lopes, Stodden, Bianchi, Maia, \& Rodrigues, 2012; Wrotniak, Epstein, Dorn, Jones, \& Kondills, 2006). In this way, children may find it easier to participate in a physical activity requiring different fundamental movement skills or more advanced level of skills, contributing to their engagement in a healthy lifestyle.

Despite the relevance of the current study outcomes, specifically the beneficial effects of swimming lessons on the aquatic skills and motor coordination of children, some limitations should be addressed. It was only possible to assess the aquatic specific skills after three months of swimming practice and there was no control group to further understand changes, particularly the motor coordination ones. Never theless, the period was so short that the growing effect could not explain all the changes found in motor coordination. The short intervention period should be recognised as another limitation, but this is usually a constrain of the school year. Main teaching periods last for two to three months before stopping for some time (school holidays). However, it should be interesting to find out whether after a long period or after cessation, the improvement in aquatic skills and motor coordination continued. Likewise, even though the number of students has been reduced to enable high activity time, the researchers recognise that some variation in tasks performed in each swimming lesson could occur in response to teaching styles that were used. Further studies should be developed to understand the effect of different teaching styles, different learning contexts and dose-response issues.

\section{Conclusion}

The results showed that 12 swimming lessons in 12 weeks were sufficient to cause significant enhancements in aquatic specific skills in children aged 6 to 10 years old. Moreover, motor coordination was also improved after the intervention period. The inclusion of swimming practices in Brazilian schools, at least once a week, seems to be beneficial for children's aquatic readiness and motor 
development, contributing to the increase of water safety and children's motor competence.

\section{Acknowledgements}

This work is supported by national funding through the Portuguese Foundation for Science and Technology, I.P., under the project UIDB04045/2020. The authors would like to acknowledge the support of SINTEGO, Secretaria de Estado da Educação de Goiás and Secretaria Municipal de Educação da Cidade de Itumbiara-GO.

\section{References}

Adolph, K. E. (2019). An Ecological Approach to Learning in (Not and) Development. Human Development, 63(3-4), 180-201. doi: 10.1159/ 000503823

Adolph, K. E., \& Franchak, J. M. (2017). The development of motor behavior. Wiley Interdisciplinary Reviews: Cognitive Science, 8(1-2), e1430. doi: 10.1002/ wcs. 1430.

Barbosa, T.M., Costa, M.J., Cardoso, L., Garrido, N.D., Marinho, D.A., da Costa, A.M., ... \& Silva, A.J. (2013). Reference manual for teaching and technical improvement in swimming. Lausanne, Switzerland: FINA.

Bem, T., Cabelguen, J.M., Ekeberg, Ö., \& Grillner, S. (2003). From swimming to walking: a single basic network for two different behaviors. Biological cybernetics, 88(2), 79-90. doi: 10.1007/s00422-0020340-3.

Borenstein, M., Hedges, L.V., Higgins, J.P.T., \& Rothstein, H.R. (2009). Introduction to Meta-Analysis. Chichester, West Sussex, UK: Wiley.

Brenner, R.A (2002). Childhood drowning is a global concern. British Medical Journal, 324(7345), 1049-1050. doi:10.1136/bmj.324.7345.1049.

Brenner, R.A., Taneja, G.S., Haynie, D.L., Trumble, A.C., Qian, C., Klinger, R.M., \& Klebanoff, M.A. (2009). Association between swimming lessons and drowning in childhood: a case-control study. Archives of pediatrics \& adolescent medicine, 163(3), 203-210. doi:10.1001/archpediatrics.2008.563.

Campaniço, J., Costa, A.M., Garrido, N.D., \& Silva, A.J. (2019). Competência Aquática: um valor acrescentado à Educação Básica. Motricidade, 15(1), 1-16. doi: 10.6063/motricidade. 18220

Cardon, G., Verstraete, S., Clercq, D. , \& Bourdeaudhuij, I. (2004). Research note: physical activity levels in elementary-school physical education: a comparison of swimming and nonswimming classes. Journal of Teaching in Physical Education, 23(3), 252-263. doi: 10.1123/jtpe.23.3.252.

Chan, D. K., Lee, A. S. Y., Macfarlane, D. J., Hagger, M. S., \& Hamilton, K. (2020). Validation of the swimming competence questionnaire for children. Journal of sports sciences, 38(14), 1666-1673. doi: 10.1080/02640414.2020.1754724

Clark, J.E. (2007). On the problem of motor skill development. Journal of Physical Education, Recreation and Dance, 78(5), 39-44. doi: 10.1080/ 07303084.2007 .10598023$.

Costa, A.M., Marinho, D.A., Rocha, H., Silva, A.J., Barbosa, T.M., Ferreira, S.S., \& Martins, M. (2012). Deep and Shallow Water Effects on Developing Preschoolers' Aquatic Skills. Journal of Human Kinetics, 32(1), 211-219. doi:10.2478/v10078-012-0037-1.

Denny, S.A., Quan, L., Gilchrist, J., McCallin, T., Shenoi, R., Yusuf, S., ... \& Weiss, J. (2019). Prevention of drowning. Pediatrics, 143(5), e20190850. doi: 10.1542/ peds.2019-0850.

Donnelly, J.E., Hillman, C.H., Castelli, D., Etnier, J.L., Lee, S., Tomporowski, P., ... \& Szabo-Reed, A.N. (2016). Physical Activity, Fitness, Cognitive Function, and Academic Achievement in Children: A Systematic Review. Medicine and science in sports and exercise, 48(6), 1197-1222. doi: 10.1249/ MSS.0000000000000901.

Dunlap,W.P. (1994). Generalizing the common language effect size indicator to bivariate normal correlations. Psychological Bulletin, 116(3), 509-511. doi: 10.1037/ 0033-2909.116.3.509.

Franklin, R.C., Peden, A.E., Hodges, S., Lloyd, N., Larsen, P., O’Connor, C., \& Scarr, J. (2015). Learning to swim: what influences success?. International Journal of Aquatic Research and Education, 9(3), 2. doi: 10.25035/ijare.09.03.02.

García-Hermoso, A., Alonso-Martínez, A.M., RamírezVélez, R., Pérez-Sousa, M.Á., Ramírez-Campillo, R., \& Izquierdo, M. (2020). Association of physical education with improvement of health-related physical fitness outcomes and fundamental motor skills among youths: A systematic review and metaanalysis. JAMA Pediatrics, 174(6), e200223-e200223. doi: 10.1001/jamapediatrics.2020.0223.

Gallahue, D., \& Ozmun, J. (2005). Compreendendo o Desenvolvimento Motor - Bebês, Crianças, Adolescente e Adultos. Brasil: Phorte Editora Ltda.

Hopkins, W.G., Marshall, S.W., Batterham, A.M., \& 
Hanin, J. (2009). Progressive statistics for studies in sports medicine and exercise science. Medicine \& Science in Sports \& Exercise, 41(1):3-13. doi: 10.1249/ MSS.0b013e31818cb278.

Kiphard, E.J., \& Schilling, F. (1974). Körperkoordinationstest für Kinder KTK: Manual. Weinhein: Beltz Test.

Kuzik, N., Naylor, P.J., Spence, J C., \& Carson, V. (2020) Movement behaviours and physical, cognitive, and social-emotional development in preschool-aged children: Cross-sectional associations using compositional analyses. PLoS ONE, 15(8), e0237945. doi: 10.1371 /journal.pone.0237945.

Langendorfer, S.J. (2019). Revised Scientific Review: Minimum Age for Swim Lessons. International Journal of Aquatic Research and Education, 10(4), 2. doi: 10.25035/ijare.10.04.09.

Langendorfer, S.J., \& Bruya, L.D. (1995). Aquatic readiness: Developing water competence in young children. Champaign, IL: Human Kinetics.

Lenhard, W., \& Lenhard, A. (2016). Calculation of Effect Sizes. Retrieved from: https:// www.psychometrica.de/effect_size.html. Dettelbach (Germany): Psychometrica. doi: 10.13140/RG.2.2.17823.92329.

Lopes, V.P., Rodrigues, L.P., Maia, J.A., \& Malina, R.M. (2011). Motor coordination as predictor of physical activity in childhood. Scandinavian journal of medicine \&science in sports, 21(5), 663-669. doi:10.1111/j.16000838.2009.01027.x.

Lopes, V. P., Stodden, D. F., Bianchi, M. M., Maia, J. A., \& Rodrigues, L. P. (2012). Correlation between BMI and motor coordination in children. Journal of Science and Medicine in Sport, 15(1), 38-43, doi: 10.1016/ j.jsams.2011.07.005.

Martins, V., Silva, A. J., Marinho, D.A., \& Costa, A.M. (2015). Desenvolvimento motor global de crianças do $1^{\circ}$ ciclo do ensino básico com e sem prática prévia de natação em contexto escolar. Motricidade, 11(1), 87-97. doi: 10.6063/motricidade.3219.

Martins, M., Silva, A J., Marinho, D.A., Pereira, A., Moreira,A.M., Sarmento, P., \& Barbosa,T.M. (2010). Assessment of heart rate during infants swim session. International SportsMed Journal, 11(3), 336-344.

Moreira, J.P.A., Lopes, M.C., Miranda-Júnior, M.V., Valentini, N.C., Lage, G.M., \& Albuquerque, M.R. (2019). Körperkoordinationstest Für Kinder (KTK) for Brazilian Children and Adolescents: Factor Analysis, Invariance and Factor Score. Frontiers in psychology, 10, 2524. doi: 10.3389/fpsyg.2019.02524. Moura, O.M., Neiva, H.P., Faíl, L.B., Morais, J.E., \&
Marinho, D.A. (2021). A influência da prática regular de natação no desenvolvimento motor global na infância. Retos: nuevas tendencias en educación física, deporte y recreación, 40, 296-304. doi: 10.47197/ retos.v1i40.83090.

Olaisen, R.H., Flocke, S., \& Love, T. (2018). Learning to swim: role of gender, age and practice in Latino children, ages 3-14. Injury prevention, 24(2), 129-134. doi: 10.1136/injuryprev-2016-042171.

Rocha, H.A., Marinho, D.A., Ferreira, S.S., \& Costa, A.M. (2014). Organização e metodologia de ensino da natação no 1 o ciclo do ensino básico em Portugal. Motricidade, 10(2), 45-59. doi:10.6063/ motricidade.10(2). 2709.

Rocha, H.A., Marinho, D.A., Garrido, N.D., Morgado, L.S., \& Costa, A.M. (2018). The acquisition of aquatic skills in preschool children: deep vs shallow water swimming lessons. Revista Motricidade, 14, 66-72. doi: 10.6063/motricidade. 13724.

Rudd, J., Butson, M.L., Barnett, L., Farrow, D., Berry, J., Borkoles, E., \& Polman, R. (2015). A holistic measurement model of movement competency in children. Journal Sports Science. 34(5), 477-485. doi: 10.1080/02640414.2015.1061202.

Scordella, A., Sano, S., Aureli, T., Cerratti, P., Verratti, V., Fanò-Illic, G., \& Pietrangelo, T. (2015). The role of general dynamic coordination in the handwriting skills of children. Frontiers in psychology, 6, 580. doi: 10.3389/fpsyg.2015.00580;

Stloukalová, B., \& Roztoci, T. (2015). Swimming as a part of early childhood education in Czech Republic. Journal of Human Sport and Exercise, 10(1), S181-S191. doi: 10.14198/jhse.2015.10.Proc1.04.

Thelen, E. (1995). Motor development. A new synthesis. The American Psychologist, 50(2), 79-95.

Wrotniak, B.H., Epstein, L.H., Dorn, J.M., Jones, K.E., \& Kondilis, V.A. (2006). The relationship between motor proficiency and physical activity in children. Pediatrics, 118(6), e1758-e1765. doi: 10.1542/ peds. 2006-0742.

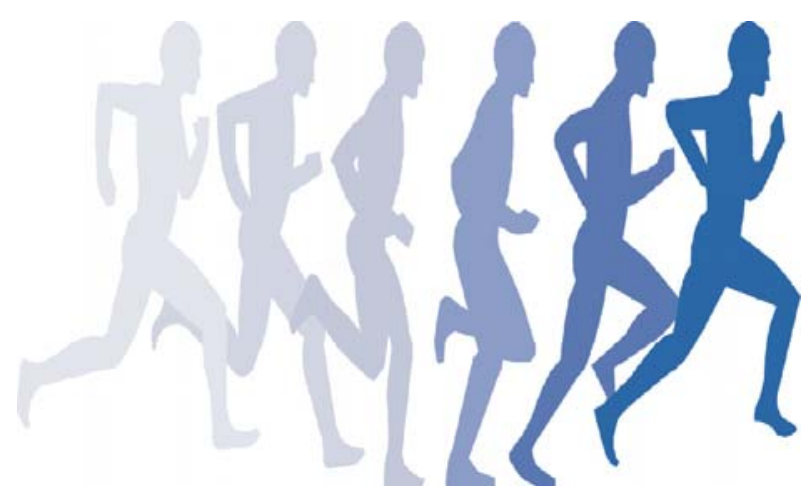

